\title{
Relações de poder na favela carioca: um breve esforço analítico
}

Les rapports de pouvoir dans le bidonville carioca: bref effort analytique

Power relations in the Carioca slum: an brief analytical sketch

Las relaciones de poder en la favela carioca: un breve resumen analítico

\section{Marek Polak}

\section{OpenEdition}

Journals

\section{Edição electrónica}

URL: http://journals.openedition.org/espacoeconomia/1141

DOI: 10.4000/espacoeconomia.1141

ISSN: 2317-7837

\section{Editora}

Núcleo de Pesquisa Espaço \& Economia

\section{Refêrencia eletrónica}

Marek Polak, "Relações de poder na favela carioca: um breve esforço analítico ", Espaço e Economia [Online], 5 | 2014, posto online no dia 22 dezembro 2014, consultado o 10 junho 2020. URL : http:// journals.openedition.org/espacoeconomia/1141; DOI : https://doi.org/10.4000/espacoeconomia. 1141

Este documento foi criado de forma automática no dia 10 junho 2020.

(C) NUPEE 


\title{
Relações de poder na favela carioca: um breve esforço analítico
}

\author{
Les rapports de pouvoir dans le bidonville carioca: bref effort analytique \\ Power relations in the Carioca slum: an brief analytical sketch \\ Las relaciones de poder en la favela carioca: un breve resumen analítico
}

Marek Polak

\section{Introdução}

O Rio de Janeiro contemporâneo, uma metrópole habitada por mais de seis milhões de habitantes - a Região Metropolitana Fluminense possui mais de doze milhos -, dos quais quase dois milhões são residentes de favelas ${ }^{1}$, que é um importante cenário de um conflito social maciço. Ao longo das últimas quatro décadas a cidade passou e ainda continua passando por uma transformação muito profunda, que traz consigo uma série de consequências sociais, que tanto podem ser vistas de forma positiva quanto como a formação de numerosas patologias.

2 O Rio de Janeiro de hoje é uma cidade de profundas divisões sociais. Um dos eixos dessas divisões é a divisão entre favela e bairros regulares. Desde quando, em 1994, o jornalista Zuenir Ventura (1994) usou o termo "Cidade Partida" - onde ele apresentou a profunda divisão sócio- econômica entre o que é chamado de "morro" (favela) e de "asfalto" (bairros regulares) - que o debate público em torno deste conceito tornou-se extremamente controverso.

3 A compreensão da divisão entre asfalto e morro apenas por categorias econômicas é demasiadamente estreita, e impossibilita o entendimento das dinâmicas sociais presentes nas favelas do Rio de Janeiro. Esse eixo de divisão de metrópole entre morro e asfalto é um conglomerado muito complexo de vários fenômenos sociais, em que o aspecto econômico não é o único fator nem determina e define de forma mais forte a complexidade do problema. 
o discurso público que tem seu lugar em torno do conflito entre a favela e o resto da cidade assumiu natureza extremamente emocional. Atualmente, ambas as partes definem suas próprias posições por meio de uma oposição profunda - "nós" contra "eles"; portanto, não entendem, geralmente, a si mesmos como um subgrupo pertencente à mesma comunidade. Em outras palavras, ambas as partes se fechavam em seu próprio significado da identidade do grupo, e definem o seu adversário como um corpo estranho o qual ameaça os seus próprios interesses. Essa abordagem reduz drasticamente a possibilidade de uma análise objetiva das fontes do conflito e a busca de possíveis plataformas de diálogo.

5 Isto é ainda mais complicado porque no Rio de Janeiro há grupos de interesse, principalmente pertencentes à classe hegemônica, que têm poder tanto político como também econômico e social, para os quais é rentável a duração do conflito atual, que tem como efeito a limitação da participação dos favelados na vida da metrópole. Portanto, usando a mídia e os meios de comunicação empregados por políticos, a imagem pública do conflito entre a favela e o resto da cidade está sendo manipulada, distorcida e, pior ainda, alimentada.

6 Neste sentido, no discurso contemporâneo, no qual se busca as fontes de conflito entre favela e o resto da cidade, pode-se encontrar duas tendências principais de avaliação da situação, basedas em ideologias que representam a esquerda e direita [em amplo entendimento de ambos os termos]. As opiniões vinculadas com lado direito do espectro político veem na favela a fonte da maioria dos fenômenos sociais negativos presentes no Rio de Janeiro, e raramente encontra-se uma tentativa de analisar as fontes das "patologias" presentes na favela. Não se vê que a violência, que constitui um dos maiores problemas sociais da metrópole, é um fenômeno muito mais complexo do que é descrito - favelados são identificados com violência. Enquanto isso, o processo de pacificação das favelas no Rio de Janeiro apenas confirmou e clarificou que o percentual de bandidos nestes bairros é constituído de uma pequena margem da população total.

Quando aparecem as tentativas de encontrar as fontes de patologia, geralmente indicase a tendência para organizar atividade criminosa vagamente inscrita na natureza dos habitantes da favela. Na mesma linha, buscam-se as fontes de marginalização tanto social como econômica e cultural, prestando atenção ao subdesenvolvimento civilizatório, resultando vagamente de limitações intelectuais e mentais. Em outras palavras, imputa-se que favelado é preguiçoso e não tem as habilidades que lhes permitiriam a integração económica. É culturalmente pobre, indeterminado em sua identidade, o que não permite que seja tratado de forma normal no sentido social.

8 Enquanto isso, a esquerda está tentando analisar o fenômeno a partir da perspectiva da teoria clássica da luta de classes, em que o acesso aos meios de produção constitui a dominação da classe hegemônica sobre a classe operária. Indica, portanto, principalmente as fontes econômicas como aquelas que constituem conflito social. Para além do fato de que a análise limitada apenas a questões econômicas parece não esgotar vasta gama de fontes (não necessariamente dispostos em qualquer hierarquia) de abismo social, o qual separa a metrópole, esta abordagem traz também outras consequências. Em termos de esquerda, favelado é visto como uma vítima do sistema existente. As soluções propostas são baseadas na abordagem que reconhece a favela como um espaço que precisa de ajuda.

9 Nossas experiências com a favela permitem apontar que os favelados não querem ser tratados como vítimas do sistema existente, e tampouco pretendem que alguém 
externo ao seu convívio imponha-lhes suas formas de organização social ou esbocem o caminho de desenvolvimento. $O$ postulado com a qual pode se encontrar é a demanda por oportunidades iguais.

10 Este postulado não pode ser realizado pela política do confronto, geralmente defendida pela "direita". Sem embargo, também a visão da esquerda não permite a implementação deste pedido, pois esta, por razões bastante diferentes das da direita, tampouco não empodera o morador da favela, colocando-lhe em pé de igualdade com os outros habitantes da cidade, pois vê nele a vítima, alguém que precisa ser tratado de uma maneira diferente. E, não pode-se neste caso discutir sobre a vantagem ética desta proposta, porque isso obscurece o quadro geral.

11 Uma tentativa de análise, usando uma abordagem holística das fontes e causas do conflito social atual, encontra uma rede de relações extremamente complicada com elementos entrelaçados provenientes de várias áreas da vida social da cidade. A literatura científica descreve alguns deles de forma abrangente, como, por exemplo o aspecto econômico ou o processo histórico de criação das favelas, sua constituição no universo socioeconômico ou socioespacial da cidade. Outros aspectos são descritos de uma forma que não esgota a problemática.

Do ponto de vista da análise levantada, parece justificado realizar este breve esforço analítico, que busca sistematiza vários aspectos do conflito entre a favela e o resto da cidade. Portanto deve-se distinguir os aspectos sociocultural, sociopolítico, sociogeográfico e socioeconômico. Cada um dos elementos analisados não foi "criado em um vácuo"; é o resultado da evolução das relações humanas, das dinâmicas sociais que ocorreram ao longo de mais de cem anos desde o final do século XIX, quando nos morros da Providência e de Santo Antônio (MATTOS, 2007) surgiram as primeiras comunidades intituladas favelas.

13 A situação em que se encontra a favela contemporânea no que se refere ao fenômeno da criminalização da pobreza tem sua historicidade. Não é possível avaliar esta questão esquecendo a materialidade histórica do fenômeno da marginalização social no Brasil e as suas implicações que resultaram para a vida social, pois assim privamo-nos de uma imagem completa do fenômeno, e, portanto, da possibilidade de entendimento. Por isso, o contexto histórico, ao lado da análise de cada um dos aspectos enumerados acima, é essencial, e sua omissão impede a compreensão das circunstâncias específicas do Rio de Janeiro e de suas indefiníveis imponderabilidades.

Neste esforço analítico, nosso objetivo consiste as relações de poder nas favelas e suas consequências para a formação da personalidade tanto no sentido de grupo, como também no do indivíduo. A favela, operando no espaço do tempo em forma de enclaves, criava não apenas as formas culturais em separação ao resto da cidade; um processo semelhante ocorre no sentido das relações de poder, pois, à medida que os governos oficiais por longos períodos de tempo não exerceram um controle efetivo sobre o território e o espaço da favela, desenvolveram-se nelas as estruturas paralelas.

15 Significativamente, pode-se falar de duas fases principais: na primeira, o poder político na favela estava exercido pelos assim chamados "bicheiros", ou seja, proprietários de negócio associado ao jogo ilegal. Mais tarde, com o advento de medidas poderosas ligadas ao tráfico de drogas e estruturação dos grupos criminosos, o poder nas favelas começou a ser captado pelas "milícias" e "comandos". Em ambos os casos, é possível provar que estes poderes tinham uma característica patrimonial e, aprofundando-se na temática, encontrar atributos de definição do conceito de totalitarismo em suas 
realidades. A permanência deste poder implica em certas consequências, pois, como provaram pesquisadores como H. Arendt ou E. Fromm, o funcionamento de ambos - os indivíduos e as comunidades - sob a influência totalitária impacta na formação da mentalidade política e compreensão da dinâmica das relações de poder na sociedade.

As sociedades habitantes das favelas, há gerações, vivem sob um determinado tipo de poder, que é estranho para os residentes dos bairros regulares. Portanto, a compreensão do poder, seus privilégios e responsabilidades é completamente diferente. Isto leva a uma situação em que ambos os grupos atribuem a certos termos significados diferentes. Em outras palavras: usam termos semelhantes, entendendo por detrás deles conceitos muito diferentes. Este fenômeno é, sem dúvida, um dos elementos que constituem tanto o conflito, como também a falta de diálogo entre o morro e asfalto.

\section{"Morro" e "Asfalto": tentativa de identificar fontes de conflito - 0 aspecto sociopolítico}

\section{Esboço histórico}

De um ponto de vista histórico, no Brasil sempre existiram os espaços de exclusão, que ficavam além da lógica do sistema existente (seja em tempos escravidão ou no capitalismo em suas várias fases, nos dias da República). No início, eram as tribos indígenas, que resistiram colonizadores, depois os quilombos, seguidos por seus "sucessores culturais", as favelas. Apesar do fato que estes espaços existiam fora da lógica do sistema existente, tanto em termos legais, como políticos, econômicos, ou culturais (quilombos, muitas vezes tinham obtido tão vasto alcance da autonomia durável que se pode falar de organizações estatais separadas) sempre ficavam em estreita relação antagônica com o mundo "oficial". Historicamente, os espaços, tanto dos quilombos, como agora das favelas, são marcados por estigmas, que assumem uma função dual pelas comunidades remanescentes dentro da lógica do sistema.

Em primeiro lugar o medo (e a alienação resultante) do favelado, que representa a ameaça para o residente do distrito regular (por causa do simples fato de ser diferente em termos de cor da pele, comportamento, expressão, etc.) constitui uma função do mecanismo de definição do adversário social, e falando sem rodeios, do inimigo. 0 homem como um ser social na perspectiva do inimigo está à procura de outros membros da comunidade que definem a ameaça de forma semelhante, e assim se unem contra um inimigo comum ${ }^{2}$. No mundo da política contemporânea, este comportamento traduz-se diretamente para a legitimidade do poder, e assegura e promete levar a luta contra um oponente claramente definido.

19 Este mecanismo, historicamente, possibilitava unir-se contra a ameaça iminente de fora, que poderia tratar-se dos animais perigosos em tempos pré-históricos ou dos adversários políticos claramente definidos em tempos das guerras modernas. No entanto, neste caso o mecanismo é usado de uma forma perversa, pois o desejo primordial de proteger a si mesmo e seus próximos em grupos maiores é usado contra os homens da própria tribo, compatriotas, residentes da mesma cidade.

20 Em segundo lugar, o medo (e alienação resultante) que resulta do estigma, com a qual o favelado foi atribuído, tem um efeito na percepção do mundo de uma maneira dicotômica, com base na oposição social "nós"-"eles". Este fato cria uma perspectiva 
superficial do mundo circundante, pois nenhuma das partes desta dicotomia está à procura de pontos em comum, mas, pelo contrário, define a realidade social com base em diferenças. Isto ocorre por estas partes procuram no outro lado os atributos, valores, comportamentos, atitudes que conflitem com os seus próprios, implicando como principal consequência a criação da impossibilidade de qualquer tipo de integração social dentro do organismo urbano.

21 A falta de integração traz consigo muitos fenômenos negativos, dentre os quais a desconfiança mútua é a manifestação mais branda e a escalada da violência uma das formas mais drásticas. Na verdade, há uma casta social para a qual a situação de falta de integração, hostilidade aberta e uma sensação de perigo são favoráveis. Esta classe dominante é capaz de providenciar para si uma vida fora dos problemas de violência na cidade, graças às funções da alienação social que fornece por si só um mandato $\mathrm{e}$ legitimidade política a suas ações. A falta de integração social e exclusão dos favelados mantém um estado no qual os bens produzidos na cidade (materiais e imateriais) são redistribuídos entre um grupo dos recebedores muito menor. Em outras palavras, com a favela restando fora da lógica do sistema, não se encontrará entre os destinatários de novos investimentos, como hospitais, metrôs, sistemas de drenagem, estradas, etc.

As tentativas de controlar o espaço da favela, em uma ótica histórica, tratavam principalmente de ações pacificadoras por meio de formas opressivas caracterizadas pela violência. Apesar do fato de que no início do século XXI muitas questões mudaram, e com a paulatina consolidação dos direitos humanos desde a segunda metade do século $\mathrm{XX}$, é significativo que o problema ainda se vê em categorias policiais. Neste caso, estamos lidando com violência tácita, seja na ocupação do espaço, seja na ação coletiva. A violência, seja em sentido literal ou simbólico, ainda é tratada como a ferramenta mais eficiente para as negociações entre o Estado e as camadas pobres concentradas nas favelas.

Grupos dominantes, de uma forma inegável, tentam manter o controle social sobre a população das favelas com a manutenção no discurso público dos estereótipos existentes. Isto é feito através do sistema de educação, da cultura entendida de forma ampla, da ideologia e do conteúdo da mídia. Martin Carnoy (1988, p. 95) define isto da seguinte forma:

"A hegemonia compreende as tentativas bem-sucedidas da classe dominante em usar sua liderança politica, moral e intelectual para impor sua visão de mundo como inteiramente abrangente e universal, e para moldar os interesses e as necessidades dos grupos subordinados".

o Estado tem o monopólio do uso da força e usa o aparelho criado para isso, em teoria, dentro dos limites legais. No entanto, o mero uso da força, mesmo se bem-sucedido, não garante ao poder a manutenção do domínio e continuação da hegemonia resultante dele, para o grupo que tem este poder em suas mãos. $\mathrm{O}$ uso da força pode ser eficaz, mas não garante a durabilidade do poder; para atingi-la é necessário legitimidade, que é obtida pela imputação às comunidades dos bairros regulares sua própria visão do mundo (de acordo com a definição de Carnoy) e, portanto, a criação do sentido de uma permanente ameaça do favelado. $O$ resultado desta alienação e ilusão da existência da única receita é a transferência do catálogo mais amplo possível das prerrogativas dadas às autoridades, o que leva a um processo de identificação da sociedade civil com o aparelho do Estado. A partir do ponto de vista das ciências sociais isto é um processo 
perigoso (subordinação das áreas de base, de atividades sociais de auto-organização ao aparelho estatal), e de fato contradiz a instituição da sociedade civil.

A relação estabelecida entre os grupos considerados subalternos e o Estado associado às classes dominantes, desde o Brasil Império, foi construída em clima de desconfiança. Os grupos dominantes buscavam a manutenção do status quo, enquanto os demais segmentos sociais procuravam a inserção em uma sociedade construída para excluí-los (CAMPOS, 2005, p. 66). E a favela, tanto no início da sua existência como durante do período de maior crescimento nos tempos de industrialização das grandes cidades, bem como no período pós- industrial, quando se tornou um elemento desnecessário da paisagem socioeconômica da metrópole submetida ao processo de descentralização, sempre se manteve em situação de exclusão política. Foi tratada como um corpo estranho dentro do organismo urbano. A comunidade com a qual se negocia de uma posição de força. 0 único elemento do exercício de poder presente na favela era e é a opressão policial.

Assim, a favela não era gerenciada pelas autoridades da prefeitura. A organização de sua vida cotidiana não foi regulada por nenhuma lei existente além dela. Apesar disso, sobre o espaço das favelas não se pode falar de maneira alguma como sobre uma criação anárquica. Deixada fora da lógica das autoridades legais, desenvolveu suas próprias estruturas, paralelas ao governo municipal, os quais em muitos casos executam funções idênticas. Este poder estava capaz, no espaço da história, de ser extremamente eficaz em áreas não geridas pelo legal. Além do mais, ao longo do tempo, os interesses dos grupos que executavam poder na favela, começaram a se espalhar para além de suas fronteiras. $\mathrm{O}$ efeito disso tornou-se um conflito social permanente, no qual a ilustração contemporânea é a violência que se derrama nas ruas da metrópole.

Neste panorama, após a transferência da capital do Brasil para Brasília no início dos anos 60 , o Rio de Janeiro sobreviveu a um certo freio no crescimento econômico. Foi despojado de muitos dos fundos relacionados com o fato de ser capital. Este problema foi agravado com a reforma administrativa, que resultou na liquidação do estado da Guanabara, e em seu lugar estabeleceu-se o estado do Rio de Janeiro. A cidade teve, em tese, de começar a compartilhar seus recursos com um interior muito mais pobre.

$\mathrm{Na}$ década de 80, a crise econômica da cidade começou a impor mudanças sociais profundas. 0 modo de produção industrial existente naquela época tornou-se algo que remete ao passado. Produção concentrada nos centros urbanos estava desmoronandose em um processo de descentralização. Graças às novas tecnologias e ao desenvolvimento de infraestrutura, o processo de produção moveu-se para a periferia das cidades, quebrando lentamente com o conceito clássico de centro urbano.

Com a descentralização da produção, diminuiu também a necessidade de um grande número de mão-de-obra barata, que em um cenário ideal estava localizada ao lado da fábrica. As favelas que cumpriam esse papel, de repente, perderam o sentido econômico de existência. Enormes áreas urbanas, como, por exemplo, os complexos das favelas e Maré e Alemão no Rio de Janeiro, foram subordinadas à lógica da produção, que na década de 80 começou a se afastar na história. Assim, grandes massas sociais foram submetidas a um processo extremamente brutal de pauperização, e novas patologias que sempre acompanham um aumento significativo da pobreza.

o Rio de Janeiro começou a render-se ao crime organizado, cuja fonte principal de renda tornou-se o tráfico de drogas. A crise foi usada pelo populismo. Todos esses 
fatores, como resultado, levaram a uma situação de colapso social e econômico. A década de 80 hoje é chamada de "década perdida".

\section{A questão do patrimonialismo}

31 A questão das relações de poder nas favelas do Rio de Janeiro deve ser colocada no contexto mais amplo de autoridade patrimonial, que é a característica das relações de poder no Brasil e mais amplamente em toda a América Latina. Patrimonialismo pode ser descrito como o crescimento extensivo do poder patriarcal, que extrapola, de sua dimensão caseira, pelo domínio sobre o território, as pessoas, as coisas de propriedade indeterminada e as gerencia no estilo de propriedade da família (patrimonial).

Este método de governar está profundamente enraizado na tradição brasileira, e até hoje não foi superado. Ainda atualmente tem seu reflexo em uma linguagem que é um espelho do processo histórico de formação da cultura da sociedade. Um exemplo da linguagem é mesmo o termo "tomar posse", utilizado para definir entrada em uma posição (cargo) específica em aparelho burocrático por um funcionário público. "Posse", neste contexto, sugere uma propriedade, ou apenas patrimônio. De acordo com Raymundo Faoro (1958), "o Estado tem os proprietários". A história do Brasil mais recente está cheia de exemplos de grupos que tentaram privatizar o poder.

Nos tempos de "velha república" (1889-1930), lidava-se com uma tentativa de aquisição do aparato burocrático local pelas elites regionais para enriquecerem. A chance de quebra das tendências patrimonialistas aconteceu no período do governo Getúlio Vargas (1930-1945 e 1951-1954). O projeto de modernização e industrialização do país dava uma perspectiva de mudanças na compreensão do poder entendido no conceito vertical. No entanto, essa chance foi desperdiçada. Governo altamente centralizado para facilitar a implementação das suas políticas entrou em cooperação com os poderosos, regionais proprietários de terras ou oligarcas locais. Tendências antipatrimonialistas no campo governista de Vargas representou o grupo, que foi herdeiro político de Júlio de Castilhos (1860-1903). No entanto, ele encontrou uma forte oposição entre os setores oligárquicos tradicionais, burocracia e parte dos segmentos políticos e intelectuais de proveniência liberal (VÉLEZ RODRIGUEZ, 2005, p. 182).

A segunda metade do século XX foi marcada por dois períodos, que não mudaram substancialmente a compreensão tradicional das relações de poder. $O$ retorno para a democracia não necessariamente influiu de forma modernizadora para este aspecto, pois enquanto nas grandes cidades do Brasil surgiram movimentos que apontavam para este elemento da cultura política e chamavam para sua reforma, na periferia das cidades e interior do país manteve-se e ainda permanece sob a forte influência do modelo patrimonial do poder. Exemplos que vale a pena levantar são as assim chamadas "repúblicas": "República do Maranhão" (gerida nos anos 1985-1990 por José Sarney), "República de Alagoas" (colocada sob o poder de Fernando Collor de Mello, nos anos 1990-1992), "República de Juiz de Fora" (organizada em torno da governança de Itamar Franco nos anos 1992-94) ou "República do PSDB" (que funciona sob os auspícios de Fernando Henrique Cardoso, durante dois mandatos presidenciais 1995-2003).

Estes exemplos ilustram como de uma maneira bem perigosa no Brasil obliteram-se as fronteiras entre o bem público e o serviço público e a apropriação do grupo privado no aparelho do Estado com objetivo de realização dos seus próprios interesses. Em outras palavras, pode-se dizer que há uma linha muito fina entre a compreensão tradicional 
do conceito "República" (latim. Res publica - coisa pública), e a maneira mafiosa, e, portanto, organizada no princípio do sistema do patriarcado vertical chamado cosa nostra.

A característica descrita acima das relações do poder no Brasil deve ser levada em conta quando se analisa as formas de poder baseadas em atividades ilegais, que acontecem nas favelas. Tal como será demonstrado mais adiante no texto, a atividade dos assim chamados "bicheiros" e depois gangues chamadas "comandos" se ancora perfeitamente na concepção patrimonial de poder. Portanto, pode-se concluir que a infâmia generalizada enfrentada por grupos criminosos que exerçam autoridade nas favelas é um sinal de certa hipocrisia ou esquizofrenia. 0 poder nas favelas, portanto, em uma escala local reproduz certos padrões que fazem parte da cultura política geral do país. É importantelembrar sobre o fator da escala: com o poder exercido num território muito limitado, sua abrangência patriarcal sobre quase todos os aspectos da vida é muito mais profunda, do que do lado de fora da favela.

\section{A constituição do poder na favela}

37 O primeiro período de atividades dos grupos profissionais de atividade ilegal, que começaram a exercer o poder efetivo nas favelas, pode ser indicado dentro do período de tempo dos anos 1950-1980. É um período no qual enriqueceram os assim chamados "bicheiros", ou seja, proprietários de jogo de apostas ilegais, chamado de "jogo de bicho". Seu poder econômico se traduzia em poder político. No entanto, suas atividades não levaram consigo uma escalada de violência com a qual identificamos o Rio de Janeiro contemporâneo.

Bicheiros perfeitamente se encontraram nas favelas. Nas margens da sociedade perfeitamente recriavam-se as relações de poder patrimonial e, portanto, os bicheiros tornaram-se os patriarcas das favelas. Suas atividades não se limitavam a controle do jogo e suborno de policiais que fizeram vista grossa para transações ilegais; eles espalharam sobre suas posses um guarda-chuva de mecenato. Patrocinavam as escolas de samba, que são a melhor exemplificação da vida cultural das favelas ${ }^{3}$. Eles também foram para os habitantes uma instância para qual se levava os pedidos de assistência econômica, ou arbitragem nas disputas entre os residentes.

A "patronagem" dos bicheiros deu às escolas uma dimensão econômica e social até então impensável (...). As escolas recebiam de suas comunidades reconhecimento , que era negociado com os políticos em troca da permissão da ilegalidade e do direito de lavar abertamente o dinheiro obtido no jogo. (ZALUAR, ALAVITO, 1998, p. 135)

39 A estrutura social construída em torno de bicheiros se assemelhava a estrutura da máfia siciliana. Havia um código não escrito, de acordo com o qual se devia manter os acordos, e em primeiro lugar se colocava os laços familiares e locais e honra. Um elemento importante foi a solidariedade com os outros membros do clã, e outros bicheiros que exercitavam sua autoridade sobre outro território. Em contraste, as pessoas que traíram ou não respeitavam as normas impostas eram tratadas com ferocidade. Enquanto isso, aqueles que concordaram com o "patrocínio" tiveram a oportunidade de conduzir uma vida estabilizada dentro de suas próprias comunidades.

No final dos anos 70, surgiu um novo tipo de criminoso, envolvido no tráfico de drogas: o traficante. Inicialmente, ele era um empregado do bicheiro, mas com o tempo 
começou a trabalhar por conta própria e minou a autoridade de seus ex-empregadores nas favelas.

41 O aparecimento em massa das drogas no Rio de Janeiro na década de 70 irrevogavelmente mudou a paisagem da cidade. Para o Brasil, apesar do regime militar conservador, chegavam novas tendências do ocidente. Um dos seus elementos foram as drogas, as quais, juntamente com a geração de 1968, passaram o processo de massificação na cultura popular. Nos Estados Unidos, tornaram-se um atributo inseparável dos movimentos que protestavam contra a guerra do Vietnã e que de uma maneira revolucionária iniciou uma revolução cultural em um país com fortes tradições puritanas. Drogas tornaram-se um símbolo de libertação no campo da cultura. Desta forma chegaram nos anos 70 para outras regiões do mundo. Não estavam mais um tabu, mas um objeto que simbolizava o mundo em rápida mudança e rebelião contra os valores tradicionais. Também chegaram ao mercado brasileiro.

Outro fator que influenciou o surgimento dos grupos criminosos organizados foram as mudanças sócio- econômicas dos anos 70. Nesta altura, a favela existia como a consequência de uma determinada lógica de produção industrial. O Brasil industrial, cuja construção começou na era Vargas, precisava da favela como uma fonte de mãode-obra barata. Naquela época, os centros de produção - as fábricas - concentraram-se nos centros urbanos, porque ali encontravam o melhor acesso aos meios de produção.

A favela foi uma espécie de solução para as cidades em processo do desenvolvimento. Os grandes centros industriais precisam de grandes quantidades de trabalhadores. Portanto, as favelas foram formadas ao lado das fábricas (como exemplos, os complexos de favelas do Alemão e da Maré) e tornaram-se fornecedoras de mão-de-obra barata. 0 paradoxo da formação das favelas consistiu no fato de que os imigrantes que chegavam no Rio de Janeiro foram explicitamente incentivados a ocupar locais específicos. Tentados com promessas de emprego e renda estável, ocupavam os morros. Em seguida, as mesmas autoridades que os incentivava a fazer isso, não reconheceram as novas favelas como legais, denominando este processo de ocupação como invasão. A falta de regulação das relações de propriedade na favela tem repercussões poderosas até hoje.

Até o fim da década de 70, o Rio de Janeiro cresceu de uma forma inimaginável; todavia, com o início da década de 80 do século XX, o Brasil começou a entrar na época pósindustrial, seguido por progressiva descentralização da produção. O maior papel econômico, concentrado até este tempo nas fábricas metropolitanas, começou a ser assumido pelo setor de serviços. Este setor da economia precisa de trabalhadores com um perfil significativamente diferente de um trabalhador não qualificado de fábrica da era industrial (HARVEY, 2005, p. 161-188).

Enquanto isso, o capital que permaneceu no setor industrial, juntamente com as novas capacidades tecnológicas (comunicação, mobilidade e transporte) tornou-se móvel, deslocando sua produção a lugares onde o trabalho é muito mais barato e disponibilidade infraestrutural é maior. Junto com essa mudança, a favela perdeu sua importância econômica como fonte de mão-de-obra - ainda que seus moradores ofereçam a mão-de-obra necessária para toda a sorte de serviços das áreas mais abastadas da cidade. Neste "re"-planejamento, indica-se a possibilidade de fazer com que este trabalhador migre para áreas mais distantes, e desafie o tempo e o espaço atravessando grande parte da região metropolitana fluminense para chegar ao trabalho. 

conceito de governo neoliberal entende a política (pública também), de maneira deliberada, como possibilidade de obter cada vez mais lucro econômico. Nesse arranjo, a favela tornou-se um grave problema, e assistiu a um processo de empobrecimento progressivo.

47 É inevitável, como resultado do empobrecimento, o crescimento de fenômenos patológicos - termo que aqui deve ser entendido como liberto de vínculos conceituais pretéritos. A favela vem sendo excluída da vida econômica, e, como resultado, da vida política e social também, o que derivou cada vez mais em "delinquência". A falta de perspectivas das novas gerações causou fuga para as drogas e fontes de renda ilegais.

O outro elemento que influiu na constituição do poder de novos grupos criminosos envolvidos no tráfico de drogas nas favelas foi uma política míope das autoridades penitenciárias do estado do Rio de Janeiro. A experiência de muitos eventos históricos decisivos indica que a colocação em massa nas mesmas celas de prisão presos políticos junto com criminosos trouxe para o governo consequências desastrosas. Bicheiros ainda desfrutavam sua onipotência nos morros do Rio de Janeiro, quando nas paredes de concreto, as quais completamente não correspondiam com a paisagem paradisíaca da praia de Dois Rios, na Ilha Grande (RJ), fechavam-se os pequenos traficantes de drogas.

Quando a grade batia atrás deles, entre os novos colegas, frequentemente encontravam pessoas aparentemente completamente incompatíveis (em sua opinião) para as circunstâncias da prisão. Conheceram lá os jovens, quem falavam sobre as grandes ideias, a luta contra a opressão e a ditadura. Também os caracterizava o fato de que, a princípio, nenhum deles tinha cometido alguns crimes concretos (na percepção de um traficante de drogas). Chamavam um ao outro "camarada" e criavam uma grande rede de "auto-ajuda". O fato de pertencer à mesma organização (partido político, por exemplo) significava que foram capazes de sacrificar-se um para o outro, mesmo sem pessoalmente conhecer-se. A dada um deles foi atribuído com um papel e as responsabilidades específicas para o cumprir. Em outras palavras, foram bem organizados dentro da rede dos vínculos baseada na lealdade e nas ideias do movimento. Isto foi algo que os traficantes dos morros ainda tinham que aprender.

$50 \mathrm{Na}$ praia de Dois Rios, na Ilha Grande (RJ) ainda existem os muros cinzas da penitenciária. Hoje dentro deles já não há prisioneiros, mas um pequeno e modesto, mas muito inspirador museu. Recolheu-se nele uma coleção única de documentos que mostram como criminosos comuns das ruas dos morros do Rio de Janeiro se transformaram em uma organização bem organizada e liderada com eficiência por trás dos muros da prisão.

51 Lá na praia de Dois Rios, nos anos 70, foi criado o Comando Vermelho, uma organização cujo só nome provoca nervosismo entre os cariocas contemporâneos. Foi fundado para ser uma gangue poderosa capaz de executar as operações em grande escala - a ocupação de morros - a subordinação a si mesmo da vida social das favelas, qual dispõe com próprio aparelho organizador, da violência e, por vezes da judiciária.

52 O nome "Comando Vermelho" não é acidental: é o resultado do dever das lições da história não feito pelas autoridades penitenciárias do Estado do Rio de Janeiro. "Comando" é a liderança, o centro de decisão, e "Vermelho" é a cor dos comunistas, os presos políticos, que foram a inspiração e os "professores" para os criminosos, foram os 
que tornaram possível transformar a patologia social marginal em uma máfia poderosa que irá deixar sua marca no destino da cidade pelas próximas quatro décadas, até os dias atuais ${ }^{4}$.

No início dos anos 80, durante a primeira administração de Leonel Brizola, as favelas se transformaram em fortalezas fechadas do crime organizado. Os comandos operavam em uma forma muito mais agressiva e brutal do que os bicheiros. Traficantes inicialmente funcionavam como funcionários dos bicheiros, mas uma mudança radical em seu estado ocorreu com o advento da cocaína no Rio. 0 enorme dinheiro do tráfico com esta droga levou à emancipação do grupo até então subordinado. Parte dos bicheiros, como, por exemplo, Aniz Abraão David, mudou o perfil de seu negócio e também se envolveu no tráfico de drogas (VELEZ RODRIGUEZ, 2005, p.188). Com o surgimento de novos grupos criminosos, a tomada do poder foi realizada pelo estabelecimento de terror absoluto.

Nos lugares onde os traficantes e comandos assumiam o controle, mudava-se a hierarquia do poder. Na parte superior do organograma de poder localiza-se o chefão, que é responsável pela compra de drogas de fora, sua distribuição e para fornecer as armas. Atrás dele, na nova hierarquia de poder na favela, está situado o gerente, seguido pelas pessoas responsáveis por pontos específicos de venda de drogas. Estes são responsáveis por vendas no varejo e atingimento do lucro. Abaixo deles na hierarquia são os soldados - equipados e treinados frequentemente pelo chefão $0^{5}$. Na parte inferior da escada de poder entre os traficantes nas favelas estão os observadores, que relatam o aparecimento de perigo (geralmente a polícia ou um grupo competitivo) com uso de signos estabelecidos (pode ser, por exemplo, pipas ou fogos artificiais).

As relações de poder dentro do grupo são baseadas na autoridade indiscutível, e são de caráter vertical. $O$ poder sobre a comunidade da favela é imposto principalmente pelo terror. O dono do morro - chefão - é um "sátrapa", tem poder sobre a vida e a morte das pessoas que estão sob sua dominação, e que são vagamente seus reféns. Eles têm todo o poder na favela. As suas decisões têm força de lei e são imediatamente postas em prática. Ele também tem o poder de emitir um julgamento e sentença tanto para os moradores da comunidade, bem como para as pessoas de fora, como no caso do jornalista Tim Lopes $^{6}$. Qualquer pessoa que não está diretamente relacionada ao tráfico de drogas deve ser maleável aos desmandos dos traficantes. A primeira e fundamental regra é o princípio de permanecer em silêncio. A todas as pessoas na comunidade é exigido fingir para o mundo exterior que nas favelas não existem grupos organizados. Esta é uma ferramenta fundamental, que permite permanecer anônimo em um confronto com a polícia.

Sem embargo, os traficantes são também pessoas que ficam fiéis a si mesmos, às famílias dos membros do comando, e às vezes também em relação aos moradores da favela governada por eles. Os chefes dos morros cuidam dos membros do comando que foram enviados para a prisão, ajudam as famílias dos traficantes mortos. Também a eles pedem ajuda pessoas que não têm ligação com o tráfico e que têm vários tipos de problemas (principalmente econômicos) ${ }^{7}$. É, portanto, um jeito de agir da organização de uma forma um pouco parecida com as estruturas criadas pelos clãs da máfia italiana, tanto na Itália como na primeira metade do século XX nos Estados Unidos.

Outro elemento que se assemelha às formas de agir da máfia são as atividades as quais corrompem alguns setores da polícia. Pequenos subornos já existiam nos tempos dos bicheiros. Sem dúvida, na época dos traficantes e comandos, esta prática mudou. 
Dentro da polícia há grupos que realizam a extorsão aos patrões dos morros, em troca de "proteção" e permissão para o tráfico. São famosos também os casos de uso pelos traficantes das armas que "desapareceram" dos armazéns policiais. Portanto, pode-se supor que policiais corruptos vendem as armas nas favelas.

Usando estes métodos os donos dos morros fornecem um poder total sobre seus "empregados" e comunidades que se tornam reféns de sua autocracia. Os sociólogos que estudaram os mecanismos de funcionamento dos cartéis de drogas na Colômbia chamam a esse sistema de agir "clientelismo". O sistema baseia-se no servilismo, que é aplicado principalmente através do medo8.

No entanto, o medo não é o único elemento que explica o funcionamento do sistema. Cada chefão age de uma maneira um pouco diferente. Alguns se baseiam apenas no medo, outros, especialmente ao longo do tempo, depois de consolidar seu poder, começam a usar os outros métodos. Começam a agir de uma forma que assemelha-los aos bicheiros. Organizam eventos, geralmente o baile funk, trabalhos para melhoramento das condições de vida das partes mais pobres da favela (que traz à mente as atividades de Pablo Escobar como famoso "filantropo" na Colômbia). Oferecem patrocínio aos artistas locais que criam música (muitas vezes tornando-se a inspiração para as mesmas!), tornam-se figuras públicas, por vezes na forma de celebridades locais. Especialmente os jovens são fortemente influenciados por este tipo de interação, pois os membros da gangue têm as meninas mais bonitas, o dinheiro e os carros. Armas aos seus olhos param de ser um símbolo de opressão, e tornam-se um símbolo de status. Criminosos locais assumem para a juventude o papel de heróis. Assim, cria-se outra rede de vínculos, a qual constrói relações de poder projetadas na favela. Baseada não sobre a violência, mas sobre a adoração e autoridade. Neste caso, o poder dos criminosos se baseia no respeito, que resulta de um arquétipo particular de um homem bem sucedido construído por eles.

\section{A natureza do poder na favela}

60 O esboço histórico de formação das instituições do poder nas favelas, bem como sua descrição sumária, implica certas conclusões. Do ponto de vista da ciência política, vale tentar analisar as relações de poder $^{9}$ a partir da perspectiva existente na literatura científica quanto a formas de governo e sistemas políticos.

61 Sem dúvida, pode ser afirmado que, entre as formas básicas classificadas em ciência política, o poder - principalmente dos bicheiros, e em seguida dos comandos - será classificado como uma forma de autoritarismo. Levando-se em consideração o que foi descrito anteriormente neste trabalho sobre o caráter patrimonial da cultura política do Brasil, formas autoritárias encontram aqui um solo extremamente fértil. Criam-se pela "inércia"! Para a elite que assume o poder parece ser uma forma óbvia de gestão. As massas gerenciadas também parecem aceitar essa forma, estando acostumadas por gerações a serem governadas desta forma. Além dos exemplos modernos de constituição do poder em base das relações patrimoniais / patriarcais de assim chamadas "Repúblicas", no Brasil encontra-se também um fenômeno mais antigo do "Coronelismo" (1889 - 1930), ou seja, o regime autoritário exercido sobre a base de uma relação dualista patrono - cliente.

62 Em busca de respostas para a pergunta sobre uma forma específica, parece razoável colocar a tese do poder com características totalitárias existentes na favela. Sem 
controle social real, funcionamento fora dos códigos legais e operando na forma de enclaves ou guetos, fez as relações de poder na favela evoluírem a partir de formas autócratas (como coronelismo, ou mencionadas "repúblicas") para formas totalitárias.

Começando uma análise dessa questão, deve-se principalmente discutir a questão do totalitarismo de uma perspectiva teórica, para em seguida olhar os fenômenos específicos de relações de poder na favela e encaminhá-los para o modelo construído.

\section{O Totalitarismo e o "Totalismo" - questões teóricas}

64 O conceito de totalitarismo é uma tipologia utilizada por cientistas políticos para encapsular as características de uma série de regimes do século XX que mobilizaram populações inteiras em apoio do estado ou uma ideologia. De acordo com estas aproximações históricas, os regimes totalitários são mais repressivos do pluralismo e dos direitos políticos do que os autoritários. Sob um regime totalitário, o Estado controla quase todos os aspectos da vida do indivíduo. Governos totalitários não toleram atividades por indivíduos ou grupos como sindicatos que não são direcionados aos objetivos do Estado. Os regimes totalitários se mantêm no poder por meio de polícia secreta, propaganda divulgada pelos meios de comunicação, eliminação da crítica aberta ao regime, bem como a utilização de táticas de terror. Ameaças internas e externas são criadas para unir a sociedade em torno do medo.

O inspirador da palavra "totalitarismo" é considerado o líder dos fascistas italianos: Benito Mussolini. Ele falou sobre a "vontade indomável de totalitarismo" e explicando o que é o totalitarismo: "Tudo dentro do Estado, nada fora do Estado, nada contra do Estado"10. Em seu livro de 1936, Revolução Traída, Leon Trotsky aplicou o termo tanto ao fascismo, como também ao stalinismo como aos "fenômenos simétricos". Hannah Arendt (1906-1975) popularizou o uso do termo totalitarianismo (principalmente no seu livro 1951, As origens do totalitarismo), a fim de ilustrar as semelhanças entre a Alemanha nazista e a União Soviética stalinista.

A característica básica do totalitarismo é um sistema partidário, o qual adota uma ideologia, que é a base para a organização do Estado, a subordinação ao partido de todas as esferas da vida pública: o legislativo, executivo, judiciário e os meios de comunicação, o sistema de educação, arte, departamento de censura, a economia, as forças armadas e a polícia (expansão das estruturas policiais e agentes da rede secreta), enquanto, por outro lado, aplica o terror institucionalizado. 0 sistema reserva-se o direito de, ao mesmo tempo, a "alma" e "corpo", à vida e à morte, arbitrariamente determina o que é bom e o que é mau, o que é verdade e o que é mentira.

o totalitarismo é diferente da forma de governo chamado tirania ou despotismo. Os sistemas totalitários, como criações da civilização contemporânea, com base na ideologia e tecnologia, são projetados não só para o domínio sobre a sociedade no interesse de poder, mas também uma completa transformação da sociedade, em que condição é a negação da natureza humana (homem em si mesmo é nenhum), ruptura com o passado, a destruição do património cultural. A ideologia totalitária referencia-se a uma utopia específica para usá-lo para construir uma "nova sociedade" e um "homem novo". A natureza humana é negada em sua dimensão individual, familiar e nacional, rejeitam-se as conquistas das gerações, e elimina da vida social (prisão, banimento, morte) os indivíduos ou grupos sociais considerados hostis ou impróprios para mudanças. 
Totalitarismo usa métodos de outras formas de governos degenerados, como a democracia (manipulação das massas), oclocracia (uso dos indivíduos desmoralizados), oligarquia (a criação de uma nova classe de novo-rico), tirania (regra da chefia: J. Stalin, Mussolini, Hitler, Mao Tse- Tung, Pol Pot), mas finalmente as subordina não tanto aos interesses do poder ou até mesmo do Estado, mas a uma ideologia, a qual é uma síntese da política e da religião secularizada, e, assim, de facto busca o controle total da vida humana, tanto na dimensão pessoal, como social.

69 A sociedade é massificada e definida usando um denominador comum, tentando apagar quaisquer diferenças ou formas de pluralismo. É descrita por certas características, atribui-se a ela objetivos, sonhos ou desejos coletivos. $O$ individualismo é visto como uma forma de traição ao resto da sociedade fundida com os laços dos valores comuns. Dentro do regime totalitário exerce-se a luta contra as unidades e comunidades (classes ou nações) interiores ou exteriores, que foram reconhecidas como hostis.

70 O Homem é desapropriado de sua subjetividade, de sua própria natureza, existência individual, para submeter-se inteiramente ao poder político, o qual graças ao desenvolvimento da tecnologia tem as ferramentas para aprofundar o processo de tal subordinação. Como resultado se reduz ou mesmo se elimina o campo de autodeterminação individual (poder decidir tudo) para transformar a vontade humana em uma liberdade entendida como "a necessidade consciente", que na verdade é uma negação da liberdade. $O$ homem não possui direitos.

71 Totalitarismo é um termo que se refere tanto à forma de governo exercido no país, bem como às relações do poder. Discutindo a questão da favela e formas de poder nela geradas deve-se estar ciente das questões de escala. As relações de poder analisadas se relacionam a grupos relativamente pequenos, enquanto o termo totalitarismo é aplicado em relação a todas as nações. No entanto, parece ser razoável, sendo honesto aos fundamentos teóricos do totalitarismo e tendo todo o tempo atenção a questão da escala, levantar a análise das relações de poder produzidas nas comunidades pelo prisma do seu caráter totalitário.

72 O termo totalitarismo, como foi mencionado anteriormente, é um tipo de ideal, na prática não ocorrendo na plena forma da definição. Historicamente, os sistemas existentes muitas vezes se aproximavam dele, no entanto, nenhum deles cumpriu todos os pressupostos teóricos, tanto em termos da organização do poder e do aparelho da violência, como também no sentido das mudanças sociais e relações inter-humanas. $O$ problema analítico, no entanto, é a fronteira entre o poder do caráter autocrático e totalitário. Este problema também ocorre na dimensão da análise proposta neste artigo.

A fronteira entre estes sistemas não está claramente delineada na literatura científica. Não obstante, podem-se fazer algumas distinções que, sem dúvida, facilitam a interpretação.

74 Em primeiro lugar, como mesmo o nome do totalitarismo sugere, é um sistema que abrange quase todos os aspectos da atividade humana. Não se concentra apenas na monopolização do poder político (como o autocrático), mas também reivindica o direito de controlar outros aspetos como cultura ou economia. Impacta os elementos culturais como a língua (novilíngua ou novafala), domina a arte, e nega religião e transcendentalismo. Na esfera econômica visa subjugar e controlar a comercialização de bens e produção na área sobre na qual exerce o poder. 
75 Em segundo lugar, o totalitarismo é caracterizado pela brutalidade e violência na implementação de sua autoridade. Historicamente, os regimes totalitários deixaram uma hecatombe de vítimas humanas. Uma grande parte delas morreu como resultado de guerras causadas por regimes totalitários, no entanto as vítimas do terror interno em estados totalitários também são enormes. Autoritarismo, entretanto, mesmo que não possa existir sem o aparelho da violência, não a aplica nas dimensões presentes no totalitarismo.

76 Governos totalitários não toleram qualquer forma de pluralismo, enquanto nos regimes autoritários pode existir oposição legal. Embora seu funcionamento seja dificultado e restrito, ela tem a possibilidade de articular suas opiniões. A característica que difere os dois sistemas é também a natureza da função do líder. No autoritarismo o líder é uma personagem-chave na existência do sistema. Com a perda do líder, autoritarismo acaba, é incapaz de viver sem o seu carisma. Entretanto, em sistemas totalitários indica-se à personagem do líder uma função. Geralmente, ele concentra em suas mãos o poder ditatorial, sem embargo, é cercado por uma máquina burocrática tecnologicamente eficiente, que no caso de sua saída é capaz de colocar em seu lugar um novo líder que se tornaria uma continuação funcional de seu antecessor.

77 Analisando as relações de poder na favela através do prisma das diferenças descritas acima, parece justificado apresentar a tese sobre sistema de relações de poder na favela como totalitário e realizar uma análise dele.

78 No entanto, há um consenso na ciência política sobre o papel da ideologia como um elemento que constitui totalitarismo. Ideologia é o conceito que absolutamente assume o papel principal. Na ideologia ancora-se a política, e sua característica principal é a apoteose do Estado e a subordinação de todos os aspectos da vida social. Ela estabelece uma meta de transformação social. Ideologia descreve o estado ideal da humanidade, qual deve ser buscado, e assume as características da religião.

79 No sistema de poder na favela papel a ideologia não aparece em primeiro plano. Apesar de haver algumas manifestações de apoteose nas comunidades, elas são marginais. A sociedade da favela não está sujeita a controle ideológico. Além de alguns aspectos de questões éticas e morais (como as reações à injustiça) o poder não exige dos habitantes atitudes concretas neste aspecto. Não se vê também os elementos que teriam como objetivo a transformação das sociedades das favelas em algum ser determinado, definido por posições ideológicas. Certamente, a ideologia do poder da favela não assume a forma da religião. Pode-se falar mais sobre o uso pelas relações clientelísticas dos cultos existentes para fins particulares ${ }^{11}$.

No totalitarismo, em sua forma pura (tipo ideal), o homem é subordinado a ideologia que constitui a síntese da política e da religião secularizada. Enquanto isso, no caso da favela governada por bicheiros ou comandos, podemos falar mais sobre a subordinação do homem aos interesses dos dirigentes e à estrutura criada por eles. Este item tem um significado extraordinário, porque situa a natureza das relações de poder existentes na favela em um lugar bastante inesperado em relação ao modelo puro. Apesar da existência de características dos regimes totalitários, distinguindo-os dos autocráticos, no sistema de poder na favela está faltando um dos elementos-chaves da definição.

81 Tendo em conta as condições esboçadas acima, na parte seguinte do texto o termo "totalismo" será usado entendido como um conceito que tem as características da maioria dos pressupostos da definição do totalitarismo (especialmente o caráter 
abrangente do poder, que é importante para os próximas deliberações), mas desprovido do elemento da ideologia como um fator constituinte do objetivo da existência do poder, da sociedade comunitária e dos seres ideais como aspirações, perspectivas e propósitos.

\section{O totalitarismo na obra de Hannah Arendt e as relações do poder na favela}

82 A análise das relações de poder na favela do Rio de Janeiro levantada através do prisma do modelo do poder total será baseada principalmente na obra de Hannah Arendt, As Origens do Totalitarismo.

83 A autora sustenta que a criação da situação totalitária, ou seja, das condições históricas favoráveis ao surgimento do totalitarismo é resultado não apenas do pauperização econômica da sociedade, mas como de suas consequências. O processo de empobrecimento de certos grupos sociais na sociedade capitalista geralmente anda junto com a exclusão social. O resultado é a alienação das massas. Esta alienação, de acordo com Arendt, é mais forte na esfera política e cria relações de poder extremamente verticais ${ }^{12}$.

Ao analisar esse aspecto da perspectiva histórica no caso da favela, é fácil observar os processos que cabem perfeitamente nos conceitos de Arendt. Com o aprofundamento da marginalização política e social das favelas em áreas urbanas do Rio de Janeiro progrediu também o processo de alienação tanto das comunidades, bem como dos indivíduos provenientes deles (a formação de estigmas e estereótipos). Junto com este processo nas favelas desenvolveram-se as primeiras manifestações de relações de poder verticais ancoradas no patrimonialismo e clientelismo. Inicialmente formou-se o poder dos bicheiros que ainda não estavam marcados pela brutalidade característica do regime totalitário.

85 A profunda crise econômica da década de 70, que afetou toda a cidade, bem como o processo de desindustrialização e proliferação em massa das drogas resultaram em dinamização repentina do processo da alienação das favelas. Elas encontraram-se à margem da vida social, política e econômica do Rio de Janeiro. Assim, seguindo o conceito de Arendt, as favelas encontravam-se em uma situação totalitária, que favorecia o surgimento de grupos cujos métodos de agir encaixam-se no catálogo dos processos do poder totalitário. A chegada das gangues ao poder nas favelas, chamadas comandos, é um limite histórico para além do qual se deve falar sobre a constituição do poder total.

Arendt aponta que a alienação é resultado das consequências do empobrecimento da sociedade e leva à quebra de classes sociais e relações tradicionais entre elas. 0 resultado desse processo é a atomização social e o isolamento dos indivíduos, os quais se transformam em uma massa amorfa.

Note-se que nos períodos mais intensos da crise econômica do Rio de Janeiro, as favelas estavam constituindo os espaços mais pobres. Atualmente, algumas favelas começam a escapar da qualificação de espaço de pobreza (exemplo das favelas da Zona Sul), no entanto a maioria ainda são espaços onde o padrão de vida é drasticamente diferente daquele conhecido dos bairros regulares da cidade. Junto com o processo de desindustrialização do centro urbano do Rio de Janeiro e colapso das fábricas, onde a 
maioria da população favelada estava empregada, comunidades transformaram-se em uma massa de pessoas sem emprego, renda e sustento.

No entanto, a autora aponta que o indivíduo que faz parte das massas amorfas não demonstra tendências violentas. Não se torna brutal, tampouco não o caracteriza primitivismo; é passivo, o que é efeito do isolamento social, e, portanto, é uma função da alienação. De acordo com várias fontes, inclusive as oficiais, vindas da polícia pacificadora do Rio de Janeiro, a proporção dos criminosos, membros de gangues (comandos) na comunidade oscila em torno de $1 \%$. Um exemplo pode ser a pacificação do Morro do Alemão, que antes de ação policial, de acordo com a mídia constituía a fortaleza dos narcotraficantes: de acordo com dados da Secretaria de Segurança Pública (SSP-RJ), onde antes da pacificação a quantidade de traficantes no Alemão não ultrapassava de $1 \%$, o número de traficantes foi estimado em torno de 450 pessoas em comunidade de quase cem mil pessoas.

Parece impossível que mesmo com o uso todos disponíveis meios de terror, um grupo tão pequeno seria capaz de dominar e impor sua vontade a uma comunidade grande. De acordo com Arendt, o terror não é um elemento-chave que faz o regime totalitário suficientemente poderoso para impor sua vontade para as amplas massas. Este processo é resultado mais da alienação que resulta da passividade - e como crê E. Fromm, do "conformismo", como veremos no decorrer desta análise - do que da violência.

A maioria dos moradores das favelas está tentando ter uma vida normal, organizada em torno dos grupos e instituições sociais clássicos. No entanto, o fato da alienação profunda traz como uma consequência a passividade, especialmente no aspecto político. Por isto, mesmo os grandes grupos submetem-se ao terror da minoria. Afinal, o totalitarismo é um sistema de poder que visa ao controle total sobre a sociedade, que tenta abranger quase todas as áreas da vida por meio do monopólio da informação e propaganda, ideologia, terror, ações monopolísticas e massivo mono- partido.

91 A favela vista como uma criação politicamente isolada do resto da população do Rio de Janeiro satisfaz muitas das condições descritas no parágrafo anterior. $O$ poder na favela não abrange apenas as esferas da vida em que tem interesses vitais; a vida econômica, do ponto de vista da renda, não traz aos comandos que gerenciam as favelas ganhos comparáveis com os do tráfico de drogas. Mesmo assim esta esfera também é coberta pelo "patrocínio" do poder. Por exemplo, nas favelas, há controle sobre o comércio de botijões de gás. Todas as lojas de venda de gás devem ter uma autorização para essa prática do chefão. Eles também devem pagar o imposto apropriado. Como o mercado é estritamente controlado, em troca da "proteção" e imposto, o vendedor tem um mercado garantido para o seu produto. Este é mais um exemplo de uma relação tipicamente clientelista. Muitos projetos de caráter econômico na favela são rodeados com a assim chamada "proteção", uma típica prática de gangster ${ }^{13}$ que consiste em oferecer serviço de segurança a pessoa que tem algum tipo do negócio. É claro que a proposta é "não recusável", e os "guarda-costas" cobram pelo serviço. "Segurança" é, evidentemente, subordinada ao dono do morro, e pode ser considerada como um outro tipo de imposto.

Este fenômeno também permite análises a partir de Bourdieu e Foucault, que observam que a condição para o sucesso de alguns empreendimentos na área de economia incluindo aqueles que visam o abuso de confiança dos outros - é uma vantagem integradora de um grupo de interesses específicos. Objetivo comum e sanções disciplinares anexas fazem a probabilidade de deserção de seus membros diminuir ${ }^{14}$. 
93 Em 2013, as autoridades do Rio de Janeiro tentaram organizar um evento esportivo no Complexo do Alemão, que supostamente estava pacificado. Além do fato de que houve um tiroteio, as autoridades do complexo decidiram demonstrar a complexa realidade do seu domínio sobre a favela de outro modo. Um dia específico foi marcado, no qual foi proibido abrir qualquer negócio na favela. $O$ autor deste artigo estava neste dia no complexo de Alemão e das observações e pode asseverar que a população subordinou-se a esta ordem de forma absoluta.

94 Na favela não há um mono-partido massivo. Como mencionado acima, a percentagem dos narcotraficantes na sociedade dos favelados é extremamente baixa. Sem dúvida, há um fenômeno de lealdade social às autoridades da favela. O exemplo do Complexo do Alemão e fechamento de todos os pontos de negócio é significativo, mas não o único. Um morador da favela em confronto com os "estranhos", pessoas de fora, nega a existência de uma gangue. Ele protege-o, o que permite ao traficante permanecer anônimo. Isso acontece, provavelmente, principalmente devido ao medo de possíveis sanções; neste caso, a fidelidade é imposta pelo terror.

No entanto, há na favela também um senso de lealdade decorrente da hostilidade para o mundo exterior. Portanto, se a motivação para esconder os membros do comando, a negação de sua existência, é a lealdade ao grupo (comunidade), e não resultante de um ato de medo ou alienação, pode-se falar da existência de um impacto ideológico no individuo, sintomático para o poder de caráter totalitário. Este mecanismo não surge no vácuo informativo. É a forma criada pela propaganda, que enfatiza o papel de lealdade para os homens da própria tribo e hostilidade para o mundo exterior. Pode-se, portanto, falar de um aparelho de propaganda característico do totalitarismo. 0 mesmo mecanismo existia historicamente em todos os países destacados como totalitários.

$\mathrm{Na}$ parte anterior do trabalho eram descritas as formas de agir dos donos dos morros na esfera cultural, um tipo de atividade não traz lucros imediatos (certamente nãoeconômicos). No entanto, o "mecenato" que abraça os jovens artistas, ou mudanças do traficante para uma pessoa pública, a auto-criação em celebridade também serve ao desenvolvimento da autoridade, a criação do arquétipo do sucesso, status e das características desejadas na comunidade. Desta forma, a propaganda está influenciando, afiliando em torno do "partido" do poder mais membros potenciais e pessoas leais, ganhando legitimidade e autoridade, e converte a sociedade em sua própria imagem. Tal ação também tem outro efeito, característico para o poder totalitário. Usando tal ação rejeitam-se as leis e as instituições clássicas em favor de identificá-los com o poder que esta exercitava por décadas.

Nas favelas existe um respeitado código de leis. É produto do enclave, o qual não tem muito em comum com as instituições legais existentes fora da favela. Afastando-se da avaliação ética das regras existentes, deve-se notar que ele foi construído na situação de subordinação às normas do poder totalista. É então, por conseguinte, a negação de instituições tradicionais, o que é uma outra - de acordo com Arendt - característica de um sistema totalitário.

O elemento constituinte de qualquer sistema totalitário é claramente definido pelo poder: o inimigo. Pode assumir a forma de interno e externo. Para o nazismo foram os judeus, para os stalinistas foram trotskistas e capitalistas. Sem a existência do inimigo o regime totalitário, que usa a violência para consolidar seu poder, não tem legitimidade. Neste caso, o poder totalitário usa a mesma dicotomia existente na sociedade do Rio de Janeiro, que foi descrito durante a discussão sobre a percepção de favelas aos olhos do 
asfalto. Favela, semelhante aos distritos regulares, vê a cidade em forma de "nós" e "eles". Um representante armado do mundo externo é a polícia, que é chamada na favela usando o termo altamente conotado emocionalmente "alemão". A polícia é o inimigo, e apesar do fato de que muitas vezes é corrompida por gangues, na percepção dos moradores, criada pela propaganda, constitui uma ameaça principal.

Um elemento importante do sistema totalitário é a desumanização do indivíduo. Estudos sobre os campos de extermínio descrevem o cotidiano dos guardas da SS, a organização nazista que submeteu o individuo pela doutrinação brutal. Os oficiais de Auschwitz, depois do trabalho que consistia em tortura e assassínio de centenas de pessoas diariamente, à noite voltavam para casa, onde viviam uma vida exemplar de pais e esposos. Em um ambiente familiar jantavam, levando a casa conversa trivial. Sua moralidade não reconheceu infligir sofrimento e morte como algo negativo. Isto foi uma consequência das ações do sistema planejado do regime totalitário, o qual desumanizava o individuo ${ }^{15}$.

Nas gangues que operam nas favelas, muitas vezes os adolescentes exercem o papel de soldados. Em reportagem dedicada aos meninos envolvidos no tráfico podem ser reconhecidos os efeitos dos processos da doutrinação semelhantes, processos desumanizantes, como no caso dos membros da SS. Eles falam sobre a morte estoicamente, bem conscientes de que, assim como eles agem de forma violenta sobre os outros, em algum momento provavelmente vão perder a vida em ato da violência. $O$ sofrimento infligido aos outros e aquele que pode se tornar sua própria experiência é tratado com indiferença. Não buscam e não encontram nem em suas vítimas, nem em si mesmos, seres humanos. 0 conceito de moralidade é estranho para eles ${ }^{16}$.

Interessante é também a questão da liderança presente na teoria do totalitarismo, bem como no espaço da favela, a questão da presença de líderes demagógicos, incluindo os autonomeados, os quais (inicialmente) não têm (confiável) organização politica detrás deles. A permissão para a sua presença é (entre outras coisas) um jeito como a sociedade alienada, procura soluções (imaginárias muitas vezes) para os problemas incomodando-a. Trata-se de uma situação em que a falta de discernimento político, e a incapacidade de resistir aos grupos dominantes, cria um potencial negativo impossível de canalizar no sistema das relações de poder existente. Dominação simbólica como uma ferramenta para subordinar o mais fraco se torna a causa de atrofia (secundária) dos laços sociais e o momento em que o demagogo político, mesmo se parcialmente credível, permite que aos atores dominados a resistência contra aquilo que é (a situação dada). Daí a ameaça de "carismatização" ${ }^{17}$ da comunidade alienada justifica a alegação de que a reconstrução de estruturas das relações (também do poder) - e, assim, estabilização do sistema - é um projeto que, ao longo prazo, vale a pena para todos mesmo dominantes, como dominados. Assim o sistema criado pelos donos dos morros se consolida.

Características comuns de poder totalista na favela e do totalitarismo encontram-se muito mais. $\mathrm{O}$ gerenciamento centralizado, o sistema policial terrorista, mono-partido (no caso de uma favela - o comando único) que permanece sob o domínio da oligarquia (local no caso da favela), a eliminação física dos adversários, manipulação da lei, a chantagem, a militarização da vida (a presença de armas nas ruas das favelas), o niilismo moral, são as ferramentas e características que aparecem na literatura científica que descreve os governos totalitários, e ao mesmo tempo os elementos da vida cotidiana presentes nas favelas do Rio de Janeiro. 


\section{0 indivíduo em uma sociedade totalitária no conceito de Erich Fromm e a questão da formação humana do favelado}

103 No contexto do conflito social existente no Rio de Janeiro, tão importante quanto analisar o sistema das relações de poder presentes na favela é uma tentativa de compreender as consequências decorrentes da existência de um sistema totalista para o indivíduo que faz parte das massas que vivem na favela. Erich Fromm refere-se ao aspecto psicológico de um homem em um sistema totalitário ${ }^{18} \mathrm{em}$ sua obra 0 medo da liberdade ${ }^{19}$.

Segundo Fromm o elemento constitutivo do homem é o fato da posse de consciência de sua vida, e isso implica o conceito da liberdade. A liberdade plena faz o homem solitário, e por isso temeroso e impotente. Ter a consciência de sua vida ser subordinada às leis e caprichos da natureza e, ao mesmo tempo atravessando-os, constitui uma contradição inerente à existência humana.

O autor ressalta que o homem não é bom nem ruim, como estrutura separada da cultura $^{20}$. Ambas as possibilidades do bem e do mal devem ser vistas em termos de condições propícias para o desenvolvimento de um deles. Fromm coloca a pergunta fundamental: será que um homem tem a liberdade de escolher entre o bem e o mal?

Buscando as fontes filosóficas desta questão encontramos em Baruch de Spinoza a indicação de que só temos a ilusão de sermos livres porque somos conscientes de nossos desejos, mas não temos consciência de seus motivos. Também Leibniz ressaltou que as nossas decisões são motivadas por tendências que são em grande parte inconscientes ${ }^{21}$.

Fromm afirma que, ao considerar a questão da liberdade da vontade deve-se levar em conta um "certo homem", e não a liberdade de escolha de um ser humano em geral. Uma pessoa pode ter uma possibilidade de escolha enquanto o outro já a perdeu. Repete, seguindo Hegel, que um homem livre é aquele que age consciente de presença de uma única e extraordinária possibilidade, sabendo estar sujeito à lei da necessidade (FROMM, 1999, p. 139). Entre um número ilimitado de possibilidades não existe tal coisa como a liberdade de escolha. Homem na seleção é influenciado por condições ambientais (de classe, sociedade, família), e uma variedade de inclinações pessoais. 0 filósofo mostra que o grau de nossa capacidade de fazer escolhas está em constante mutação a cada nova situação no processo da vida; no entanto, quanto mais o indivíduo desenvolve a capacidade de escolher o bem, assim a escolha do bem no futuro é mais fácil. Entretanto, a seleção do mal é uma perda de si mesmo em uma tentativa trágica para escapar do fardo da humanidade. Deve-se lembrar que o conceito de humanidade deve ser considerado no contexto cultural (fortemente determinante), pois sem ele o homem seria reduzido a uma entidade apenas biológica ${ }^{22}$.

Este aspecto desempenha um papel significativo na interpretação dos comportamentos dos favelados e da profunda diferença, que neste aspecto difere moradores do morro e asfalto. Como consequência, também mostra que interpretar o conflito social por este prisma, entre a favela e bairros regulares, o diálogo entre as duas partes é feito em um nível completamente diferente de consciência (tendo em conta as consequências para a liberdade individual e de escolha que resultam da existência de relações de poder totalita nas favelas e sua falta fora dela). 
109 Fromm, em uma forma semelhante à Arendt, ressalta o problema do sistema totalitário, com foco no surgimento, persistência e consequências dele visto através do prisma do indivíduo. Vem de um pressuposto semelhante à Arendt que a fonte da fuga da liberdade é a alienação resultante da pauperização, e, portanto, na sua concepção, a condição de surgimento da situação totalitária.

110 Um homem livre, em circunstâncias específicas socioeconômicas, está quase condenado à alienação, e por isso porque decide tentar "escapar da liberdade". Fromm vê o totalitarismo como um fenômeno psicológico moldado por fatores de desenvolvimento socioeconômico.

111 O totalitarismo, por conseguinte, no caso da análise da favela, o "totalismo", é, portanto, um sistema modelado pelo medo (alienação) de liberdade. 0 mesmo medo, no conceito de Fromm, está perpetuando este sistema e estende a sua influência, com efeito na criação nos indivíduos submetidos a ele a uma personalidade autoritária, que resulta no surgimento de um instinto de rebanho nas massas. Caracteriza-se por um dualismo profundo, porque por um lado, entre os homens da mesma tribo personalidade autoritária é caracterizada por altruísmo e moralidade se rende ao grupo (que do ponto de vista da ética pode ser positivo). Por outro lado, a personalidade autoritária tem uma tendência a submeter-se da forma acrítica à autoridade, e caracteriza-se por uma falta de tolerância para os estranhos e uma noção forte de territorialismo.

112 Analisando as características descritas dos traços de personalidade autoritários através do prisma da favela, percebe-se que todos os elementos que aparecem em Fromm, em maior ou menor grau, apareceram nas partes anteriores deste trabalho, os quais se referiam aos favelados.

113 De acordo com o conceito de Fromm estes elementos são uma característica do que ele chama de uma fuga da liberdade. Seu efeito é a revelação no indivíduo de representações da escravidão, que o filósofo também agrupa na base dicotômica. Nessas representações estão duas formas de violência que permanecem em relação contraditória, que são o masoquismo e o sadismo. Personalidade autoritária por um lado tem a necessidade de submeter-se à autoridade, o que reduzirá a necessidade de tomar suas próprias decisões (medo da liberdade), enquanto que, por outro lado, aumenta a necessidade de compensação e forma uma tendência a dominar outros indivíduos.

114 Neste contexto, vale a pena prestar atenção ao fenômeno das relações de poder verticais na favela, previamente discutidas (e no sentido mais amplo das relações patrimonialistas e clientelistas), que se ancoram bem na teoria de Fromm. Ambas as tendências coexistem em um ser, e muitas vezes tomam a forma de mediação (síntese) entre os elementos restantes em contradição na forma de conformismo que se desenvolve no individuo.

115 Discutindo o conceito de Arendt trouxe-se a atenção para o domínio de um grupo relativamente pequeno pertencente ao comando sobre um grande grupo de moradores da favela. Foi colocada em dúvida, neste exemplo, a possibilidade de exercício do poder apenas através do terror. A alienação da comunidade foi identificada como o elemento principal, que explicaria esse fenômeno. Fromm, entretanto, aprofunda esta análise, quando aponta como a alienação - cujo efeito é fuga da liberdade - gera o desenvolvimento no indivíduo de uma série de contradições, que, eventualmente, 
levam ao surgimento da atitude conformista. Voltando, pois, ao exemplo discutido, e seguindo a tese de Fromm, pode-se afirmar que um grande grupo (quase cem mil dos habitantes) se entregou à autoridade de quatrocentos e cinquenta pessoas (poder autonomeado), como resultado do desenvolvimento do conformismo que é a representação da personalidade autoritária, e de todas as consequências sociais da sua existência.

116 O homem tem necessidades fisiológicas e, para atendê-las, tem que trabalhar; isso significa que incondicionalmente deve submeter-se ao sistema econômico em que ele está localizado (não importa a sua natureza). Como nas favelas do Rio de Janeiro cresceu uma geração que viveu e vive no mundo pós- industrial, subordinado ao poder de natureza "totalista", cujo alcance inclui as relações econômicas. A brutalidade desta dependência, que se aprofunda na favela com um fato da existência de relações do poder de natureza "totalista", leva a aumento e reforço da conformidade do indivíduo. Em consequência, isto conduz a uma alienação ainda maior, e, consequentemente, à ansiedade. A falta da liberdade do indivíduo que existe no sistema de tal dependência leva a efeito uma liquidação total da possibilidade de tomar decisões conscientes.

\section{Conceito do Hommo Sovieticus nos países do antigo bloco soviético e questão de formação humana na favela}

117 A continuação das considerações teóricas de Fromm é desenvolvida nos países do antigo bloco do Leste, o conceito de Hommo Sovieticus. Originalmente introduzido em um contexto positivo, serviu para descrever os cidadãos da União Soviética. Graças à existência do novo sistema e novo tipo de relações de poder, ao ser humano havia uma expectativa para evoluir socialmente e tornar-se melhor do que o homem no sistema capitalista.

118 Sem embargo, o termo começou a ser usado no mesmo contexto, só que para apontar as mudanças negativas na população soviética. 0 motivo principal destas mudanças foi principalmente o fato da "oni"-abrangência de todos os aspectos da atividade humana. A população tornava-se passiva, privada de possibilidades de tomar qualquer decisão. Depois da queda da União Soviética e o fim do sistema socialista nos países da Europa do leste, as atitudes desenvolvidas durante gerações apareceram com a inabilidade da população para se adaptar ao sistema, no qual é necessário se autodefinir através de decisões conscientes.

119 Os autores apontam que a criação do hommo sovieticus foi determinada principalmente pelo caráter total do sistema socialista na Europa do Leste. Gostaria de discutir este conceito no caso da análise levantada neste trabalho. Não se pode excluir a hipótese de que processos semelhantes no desenvolvimento das atitudes sociais vão acontecer nas favelas cariocas. Se as características de relações de poder na favela vão continuar do mesmo jeito, o humano na favela pode - seguindo Fromm e conceito do hommo sovieticus - encontrar-se em uma alienação tão profunda, que sua atitude em certas esferas da vida pode impossibilitar as interações sociais com o resto da cidade.

De acordo com o historiador soviético Mikhail Heller o conceito de hommo sovieticus funcionava primeiramente na URSS como determinação do próximo estágio da evolução humana (Homo Sapiens), moldado pelo sucesso do experimento social marxista $^{23}{ }^{24}$. Ao mesmo tempo, o conceito começou a funcionar em um sentido diferente, como uma descrição do processo em curso de desmoralização da sociedade 
comunista. Em 1982, o escritor e sociólogo emigrado russo Aleksandr Zinoviev escreveu um livro com o mesmo título, que é uma tentativa de descrever e analisar as relações e a mentalidade de emigrantes russos na França "contaminados" pelo comunismo. De acordo com Zinoviev (1983, p. 1444-1445):

Características da sociedade soviética são: a incerteza, liquidez, volatilidade, a ambiguidade em tudo. Trata-se dos indivíduos gelatinosos e mesmo como corpo recorda geleia. É uma sociedade dos camaleões, que é inteiramente um camaleão gigante.

Leszek Kolakowski acreditava que uma obra-chave no desenvolvimento do homo sovieticus foi o Breve Curso da História do PCUS (b), que, por suas inúmeras mudanças de acordo com as mudanças da "linha do partido" ou de eliminação de sucessivos líderes do partido, era um "manual da memória falsificada e da realidade bifurcada". As atitudes desenvolvidas por repetições de muitos anos das novas versões do "Breve Curso" levaram ao surgimento do "novo homem soviético: Esquizofrênico ideológico, mentiroso sincero, um homem pronto para automutilação mental e voluntária constante" (KOLAKOWSKI, 1989, p. 867).

Segundo eles, a mentalidade do Homo Sovieticus pode ser caracterizado pelas seguintes características:

- subordinado ao coletivo (a organização do partido);

124 - por sua atitude é característica a fuga de liberdade e responsabilidade;

- o conjunturalismo e o oportunismo;

- agressão contra mais fracos, humildade em frente aos mais fortes;

127 • falta de pensamento e de ação independente;

- expectativa de que "alguém vai fazer alguma coisa" (dar jeitinho) ;

- escravizado intelectualmente;

- desprovido de personalidade e dignidade;

- totalmente subordinado ao poder;

- isolamento do mundo da cultura, criado pela redução da possibilidade de viajar para o exterior e rigorosa censura nos meios de comunicação (e a onipresença da propaganda) ;

- falta de respeito pela propriedade comum e propenso a pequenos furtos no local de trabalho, tanto para uso pessoal e para o lucro, de acordo com as palavras de uma canção popular "Tudo pertence ao colcós (fazenda coletiva), tudo pertence a mim", ou "um saco dentro do caminhão, e o outro a mim mesmo".

Na Polônia, o termo homo sovieticus foi generalizado por Józef Tischner. Em sua interpretação, o termo tem um significado um pouco diferente. Segundo ele, homo sovieticus é:

Escravizado pelo sistema comunista cliente do comunismo- comeu bens que o comunismo lhe ofereceu. Três valores foram particularmente importantes para ele: o trabalho, a participação do poder, auto-estima. Devendo isso ao comunismo, homo sovieticus viciou-se no comunismo, mas isso não significa que em algum momento não havia contribuído para sua queda. Quando o comunismo deixou de satisfazer as esperanças e necessidades dele, homo sovieticus participou da rebelião. Contribui, em grau maior ou menor, o fato de que o lugar dos comunistas tomaram outras pessoas - defensores do "capitalismo". Aqui está o paradoxo criado. Homo sovieticus agora exige de novos "capitalistas", que vão ao atender 
aquelas necessidades que não conseguiram cumprir os comunistas. Ele é como um escravo que, após a libertação de uma prisão, apressadamente está à procura de uma segunda. Homo sovieticus é uma forma pós-comunista de "escape da liberdade" que descreveu uma vez Erich Fromm. (TISHNER, 1992) inevitavelmente precisa ser extrapolada para as discussões sobre as relações de poder no espaço urbano no Rio de Janeiro parece ser possível somente quando se cumpre um dos postulados de análise social apresentados por M. Foucault. ambas as partes não adotam como suposição que o adversário tem seu próprio racionalismo desenvolvido em um contexto cultural específico, ou para colocá-lo em outras palavras, o regime de verdade. Ambos os lados do conflito, agindo de forma isolada durante décadas, desenvolveram uma percepção diferente. Seguindo o filósofo francês, deve-se romper neste diálogo com o conceito de verdade universal ou absoluta. Reconhecer a subjetividade da verdade e o fato de que ela é produzida (não dada) em um regime específico determinado culturalmente por vários fatores. Que mecanismos existem que fazem com que o sujeito acredite na validade de certas verdades. Analisar as relações sociais existentes no regime de verdade observado, não para examiná-los do ponto de vista de seu próprio regime ${ }^{25}$. Se ambos os lados não reconhecem a existência de uma lógica de ação específica do adversário, e no retorno interpretam as ações do outro lado através de suas próprias racionalizações, este diálogo sempre terá lugar entre o surdo e o mudo. 
141 Arendt, no resumo do seu trabalho chama a atenção para a natureza específica do estado totalitário, sua "amorfia", constituída na criação das estruturas do poder paralelas, mas ao mesmo tempo cruzadas: a polícia, o exército, o partido, a administração do Estado. Isto é resultado da concentração de poder nas mãos de um ou de alguns líderes e é o efeito dos esforços para garantir o controle tanto sobre os membros do movimento que diretamente suportam o sistema, assim como toda a sociedade e as diferentes dimensões do sistema totalitário, incluindo o controle sobre o mesmo sistema do controle. Um efeito colateral dessa amorfia - de acordo com Arendt - é a imprevisibilidade da política totalitária. Uma coisa constante é a atitude de totalitarismo para a expansão. O mundo não totalitário não compreende esta criação amorfa e, ou superestima a potência material, ou não aprecia o poder potencial do país totalitários. Esta conclusão da autora de Raízes do totalitarismo reflete bem as dificuldades que o mundo não totalitário tinha com compreensão do totalitarismo ao longo das décadas da historia do século XX.

Um problema semelhante (em outra escala) constitui um conflito social poderoso, o qual atua na cena do Rio de Janeiro. o mundo da favela e o mundo do asfalto, através de várias experiências históricas associadas com sujeitos vinculados a diferentes tipos de poder tinham desenvolvido uma compreensão diferente dos fenômenos e conceitos. Os mesmos termos são preenchidos com conteúdo diferente. O resultado é que o diálogo entre os dois grupos é efetuado apenas de maneira ilusória com a mesma língua. $\mathrm{Na}$ verdade, as duas comunidades não se entendem e sem a constatação deste fato, não podem se entender.

\section{BIBLIOGRAFIA}

AMORIM, Carlos. Comando Vermelho: a história secreta do crime organizado. Rio de Janeiro: Record, 1993.

ARENDT, Hannah. Korzenie totalitaryzmu (port. As Origens do Totalitarismo). (Trad. M. Szawiel i D. Grinberg). Warszawa: Niezależna Oficyna Wydawnicza, 1993.

BARCELLOS, Caco. Abusado. 0 dono do Morro Dona Marta. Rio de Janeiro, São Paulo: Editoria Record, 2003.

BOURDIEU, Pierre. Zaproszenie do socjologii refleksyjnej (port. Para uma Sociologia da Ciência, Lisboa: Edições 70, 2004), trad. A. Sawisz. Oficyna Wydawnicza, Warszawa, 2001.

CAMPOS, Andrelino, Do Quilombo à Favela. Rio de Janeiro: Bertrand Brasil, 2004.

Carnoy, M. Estado e Teoria política. Campinas: Papirus, 1988.

FAORO, Raimundo. Os donos do poder: formação do patronato político brasileiro. 1. ed. Porto Alegre: Globo, 1958.

FOUCAULT, Michel. Poder e Saber. In: M. Barros de Motta (Org.). Estratégia, Poder- Saber. Ditos e escritos IV. Rio de Janeiro: Forense Universitária. 2003. 
FOUCAULT, Michel, Sujeito e poder. In: Dreyfus, H. e Rabinow. Michael Foucault: uma trajetória filosófica; para além do estruturalismo e da hermenêutica. Rio de Janeiro: Forense Universitária, 2010.

FOUCAULT, Michel. Verdade e Poder. In: FOUCAULT, M. Microfísica do Poder. Rio de Janeiro: Graal, 1979.

FROMM, Erich. Man for himself : an inquiry into the psychology of ethics. New York : H. Holt, 1990;

FROMM, Erich. Serce człowieka (port. O coração do homem). PWN, Warszawa - Wrocław, 1999.

FROMM, Erich, The nature of Man. New York: Macmillan, 1968.

FROMM, Erich, Ucieczka od Wolnosci. Trad. Olga i Andrzej Ziemilscy, Warszawa: Czytelnik, 2004 (versão port. O Medo à Liberdade, Tradução de Octávio Alves Velho. 14 ${ }^{a}$ Ed. Rio de Janeiro: Guanabara Koogan, 1983).

HARVEY, David. A produção capitalista do espaço. (Título original: Spaces of capital: Towards a critical geography). Tradução: Carlos Szlak. São Paulo: Annablume, 2005;

Heller, M., Maszyna i śrubki. Jak hartował się człowiek sowiecki (port. Máquina e parafusos. Como o homem Soviético estava endurecido). Warszawa: Wydawnictwo Pomost, 1989.

HERTZ Aleksander, Szkice o totalitaryzmie (port. Os Esboços sobre o totalitarismo). Warszawa: PWN, 1994;

KOŁAKOWSKI, L., Główne nurty marksizmu(port. As principais correntes do marxismo). T. III Rozkład. Wydawnictwo Warszawa: KrĄg-Pokolenie, 1989.

MATTOS. Romulo Costa. Aldeias do mal. In: Revista de Historia da Biblioteca Nacional, 30 X 2007. PRADO VALLADARES, Licía do. A invenção da favela. Rio de Janeiro: Editoria FGV, 2005.

PRADO VALLEDARES, Lícia do. A Gênese da Favela Carioca. A Produção anterior as Ciências Sociais. In: Revista brasileira de ciências sociais, vol. 15, outubro, número 44, 2000.

SALAZAR J., Alonso. La parábola de Pablo: auge y caída de un gran capo del narcotráfico. Bogotá: Planeta, 2001.

TISHNER, Józef. Etyka Solidarności oraz hommo sovieticus (port. Ética da Solidariedade e Homo Sovieticus). Warszawa: Znak, 1992;

TUROWICZ J., PamiĘć i rodowód. „Tygodnik Powszechny”. nr 45, 1993.

VALLA, Victor Vincent. Educação e Favela. Rio de Janeiro: Vozes, 1986.

VÉLEZ Rodríguez, Ricardo, The sociological dimension of the drug-traffic in the favelas of Rio de Janeiro. In: City of God in Several Voices: Brazilian Social Cinema as Action. Nottingham: Nottingham University Press 2005;

VENTURA, Zuenir. Cidade Partida. São Paulo: Companhia das Letras, 1994.

ZALUAR, Alba Maria; ALAVITO, Marcos. Um século da Favela. Rio de Janeiro: Editora FGV, 2004.

ZINOWJEW, A. Homo sovieticus. Warszawa: Polonia, 1983. 


\section{NOTAS}

1. De acordo com estatísticas do IBGE; este instituto usa o termo "aglomerado subnormal" para designar um conjunto constituído por no mínimo 51 unidades habitacionais (barracos, casas, etc.), ocupando ou tendo ocupado até período recente, terreno de propriedade alheia (pública ou particular), dispostas, em geral, de forma desordenada e densa; carentes, em sua maioria, de serviços públicos e essenciais. De acordo com o IBGE, "os aglomerados subnormais podem se enquadrar, observados os critérios de padrões de urbanização e/ou de precariedade de serviços públicos essenciais, nas seguintes categorias: invasão, loteamento irregular ou clandestino, e áreas invadidas $e$ loteamentos irregulares e clandestinos regularizados em período recente". Ver: http:// biblioteca.ibge.gov.br/visualizacao/periodicos/92/cd_2010_aglomerados_subnormais.pdf. Acesso em 10 de outubro de 2014 .

2. Nas ciências sociais, este fenômeno está vinculado à teoria da síndrome de pensamento de grupo (ing. Groupthink), que é aplicado tanto a escala de crises internacionais, bem como crises sociais locais. Veja: Turner, M. E.; Pratkanis, A. R.; Probasco, P.; Leve, C. (1992). "Threat, cohesion, and group effectiveness: Testing a social identity maintenance perspective on groupthink". Journal of Personality and Social Psychology 63 (5): 781-796; Esser, J. K. (1998). "Alive and well after 25 years: a review of groupthink research". Organizational Behavior and Human Decision Processes 73 (2-3): 116-141.

3. No livro "Um século de Favela" (1998), Alba Zaluar e Marcos Alavito usam o termo "carnavalização do poder" (p. 132-135) para descrever o poder desempenhado por bicheiros em escolas de samba e em forma mais ampla em vida cultural da favela.

4. O fragmento dedicado para Comando Vermelho ancorei nas experiências levadas de visita em Museu do Cárcere (MUCA) - ver : http://museucarcereuerj.blogspot.com.br/ - localizado na praia de Dois Rios na Ilha Grande - município Angra dos Reis, RJ, e também na base de leitura: Amorim C., Comando Vermelho: a história secreta do crime organizado. Rio de Janeiro: Record, 1993.

5. A hierarquia do poder é descrita no base de artigo citado: VELEZ RODRIGUEZ, 2005, p. 188.

6. Ortiz F., Morte de Tim Lopes foi "caso anunciado", diz colega que fugiu do país após ameaça de traficantes, Noticias UOL, 16/07/2011. Disponível em: http://noticias.uol.com.br/cotidiano/ ultimas-noticias/2011/07/16/morte-de-tim-lopes-foi-caso-anunciado-diz-colega-que-fugiu-dopais-apos-ameaca-de-traficantes.htm.

7. Este jeito de agir é descrito em: Barcellos, 2003, p. 92-93.

8. Problemática de formas de agir de cartel colombiano comandado pelo Pablo Escobar foi descrita das posições sociológicas em: SALAZAR J., 2001.

9. Poder como relação social, não apenas instituição vê Michel Foucault. Veja: FOUCAULT, M., Sujeito e poder, In: DREYFUS, H. e RABINOW. Michael Foucault; uma trajetória filosófica; para além do estruturalismo e da hermenêutica. Rio de Janeiro: Forense Universitária, 2010, p. 273-295

10. Mussolini B., The doctrine of fascism, Rome: Ardita Publishers, 1932, p. 7-42; http:// www.worldfuturefund.org/wffmaster/reading/germany/mussolini.htm.

11. Significativo neste sentido é o caso de organização Afro Reggae e seu conflito com pastor Marcos no Morro do Alemão. Existem acusações que as posições deste pastor citado correspondem com a poítica do comando que manda a favela. Coincidentemente, depois de escalada do conflito entre o pastor e José Junior - o líder do Afro Reggae - a sede da organização foi queimada, e mesmo J. Junior se "auto-baniu".

12. Os todos aspetos discutidos da teoria de H Arendt seguem: Arendt H., Korzenie totalitaryzmu (As Origens do Totalitarismo), trad. M. Szawiel i D. Grinberg, Warszawa: Niezależna Oficyna Wydawnicza, 1993.

13. As formas de agir de caráter de gangster, como uma natureza do totalitarismo acentua Norman Davies em: 
Norman Davies: Europa. Rozprawa historyka z historiĄ. (A Europa. O historiador discute com a história) Kraków: Wydawnictwo Znak, 1999, s. 1017-1026.

14. Por: Bourdieu P., Zaproszenie do socjologii refleksyjnej(port. Para uma Sociologia da Ciência, Lisboa: Edições 70, 2004), przeł. A. Sawisz, Oficyna Wydawnicza, Warszawa2001, s. 104-105; Por. M. Philp, ichel Foucault", [em:] Skinner Q., Powrót wielkiej teorii w naukach społecznych (port. A volta de grande teoria nas ciências sociais), przeł. P. Łozowski, Wyd. UMCS, Lublin 1998, s. 79-99; Foucault M., Trzeba bronić społeczeństwa (potr. A sociedade tem que ser defendida), przeł. M. Kowalska, Wyd. KR, Warszawa 1998, s. 47-48.

15. Veja: Knopp G., SS Przestroga historii, Warszawa: Świat KsiĄżki, 2004. Versão inglesa: Knopp G., SS a warning from history. Sutton: Sutton Publishing Limited, 2005.

16. Veja: MV Bill, Athayde C., Falcão - Meninos do Tráfico, publicado no TV Globo, em programa Fantástico, 19/03/2006.

17. A. Hertz, Szkice o totalitaryzmie (port. Os Esboços sobre o totalitarismo), Warszawa: PWN, 1994.

18. Os conceitos da construção da natureza humana das obras de E. Fromm em: FROMM E., Man for himself : an inquiry into the psychology of ethics, New York : H. Holt, 1990. FROMM E., The nature of Man, New York: Macmillan, 1968.

19. Os fragmentos dedicados à teoria de Fromm de 0 medo da liberdade em: Fromm E., Ucieczka od Wolnosci, trad. Olga i Andrzej Ziemilscy, Warszawa: Czytelnik, 2004 (versão port. O Medo à Liberdade, Tradução de Octávio Alves Velho. 14ª Ed. Rio de Janeiro: Guanabara Koogan, 1983).

20. De jeito semelhante vê este conceito Foucault: FOUCAULT, M. Sujeito e poder, op.cit., p. 273-295.

21. Erich Fromm, Serce człowieka (port. O coração do homem). PWN, Warszawa - Wrocław, 1999, p. 123-124.

22. Neste conceito encontra-se uma diferença fundamental entre Fromm e Freud, quem também foi um determinista, mas reduzindo o homem até apenas um ser biológico, não levava sobre a consideração a reversibilidade da regra baseada no vinculo causa - efeito.

23. ZwiĄzek Radziecki jest (...) ojczyznĄ nowego, wyższego typu homo sapiens - homo sovieticus", em: trabalho dos muitos autores: Sowietskije ludi.(port. Os homes soviéticos) Moskwa: 1974. "A União Soviética é (...) a pátria de um novo, maior tipo de homo sapiens - homo sovieticus" - tradução do autor.

24. Heller M., Maszyna i śrubki. Jak hartował się człowiek sowiecki (port. Máquina e parafusos. Como o homem Soviético estava endurecido). Warszawa: Wydawnictwo Pomost, 1989.

25. Veja: Foucault M., Sujeito e poder, op. Cit., p. 273-295; FOUCAULT M., Verdade e Poder. In: FOUCAULT, M. Microfísica do Poder. Rio de Janeiro, Graal: 1979. FOUCAULT, M.. Poder e Saber. In: M. Barros de Motta (Org.), Estratégia, Poder-Saber. Ditos e escritos IV - (pp. 223- 240). Rio de Janeiro: Forense Universitária. 2003.

\section{RESUMOS}

A favela no Rio de Janeiro constitui um fenômeno que, no espaço das últimas décadas, evoluiu, criando vários mecanismos sociais ausentes em outras partes da cidade. 0 artigo foca a análise das relações de poder na favela a partir dos trabalhos de Hannah Arendt e Erich Fromm, apontando na direção de soluções sistêmicas típicas de sistemas totalistas, o que traz consigo várias consequências para a formação humana do indivíduo. 
Le bidonville carioca constitue un phénomène qu'a augmenté dans les dernières décennies, en créant plusiers mécanismes sociaux qui n'existent pas dans les autres espaces de la ville. L'article souligne l'analyse des rapports de pouvoir dans le bidonville carioca à partir des travaux de Hannah Arendt et Erich Fromm, en indiquant des solutions systémiques propres aux systèmes «totalistes », ce qui apporte plusiers effets sur la formation humaine de l'individu.

The slum of Rio de Janeiro is a phenomenon which, during the time of decades of evolution, has created several social mechanisms absent in other parts of the city. The article is focused on analyzing the relations of power in the slum, from the theoretical concepts of Hannah Arendt and Erich Fromm. It shows the evolution of the relations of power in the slum into direction of systematic solutions characteristic for totalistic systems, which brings with itself various consequences for human individual development.

La favela del Rio de Janeiro constituyó un fenómeno, cual en espacio de las décadas del desarrollo ha creado varios mecanismos sociales ausentes en las otras partes de la cuidad. El artículo concentra-se en una reseña de las relaciones del poder en la favela, desde los conceptos teoréticos de Hannah Arendt y Erich Fromm. El artículo apunta a la evolución de las relaciones del poder en la favela en la dirección de las soluciones sistemáticas particulares para las sistemas totalistas, lo que lleva consigo varias consecuencias para desarrollo individual del sujeto.

\section{ÍNDICE}

Palabras claves: estigma social, discriminación social, favela, Río de Janeiro, sistemas totalistas Palavras-chave: estigma social, discriminação social, favela, Rio de Janeiro, sistemas totalitaristas

Mots-clés: stigmate social, discrimination sociale, bidonville, Rio de Janeiro, systèmes totalitaires

Keywords: social stigma, social discrimination, slum, Rio de Janeiro, totalistic systems

\section{AUTOR}

\section{MAREK POLAK}

Mestre em Relações Internacionais pela

Universidade de Varsóvia e doutorando em Políticas Públicas e Formação Humana pela

Universidade do Estado do Rio de Janeiro. E-mail : marpol17@wp.pl 